\title{
Repairing Damaged Goods: Mesenchymal Stromal Cell Therapy for Secondary Failure of Hematopoiesis Post-Allogeneic Hematopoietic Cell Transplant
}

\author{
Shernan G Holtan ${ }^{1,2 *}$, Laura F Newell ${ }^{1}$, Rekha Chandran ${ }^{3}$, Svetomir N Markovic ${ }^{2}$ and Luis F Porrata ${ }^{2}$ \\ ${ }^{1}$ Center for Hematologic Malignancies, Knight Cancer Institute, Oregon Health \& Science University, 3181 SW Sam Jackson Park Rd, Portland, OR 97219, USA \\ ${ }^{2}$ Division of Hematology, Department of Medicine, Mayo Clinic Graduate School of Medicine, 200 First St SW, Rochester, MN 55905, USA \\ ${ }^{3}$ Legacy Health System, 2211 NE 139th St, Vancouver, WA, 98686, USA
}

Keywords: Allogeneic hematopoietic cell transplant; Hematopoiesis; Cytopenias; Graft-versus-host disease; Mesenchymal stromal cells

Many high-risk or advanced cancers of the blood, such as acute leukemia and myelodysplastic syndrome, cannot be cured by chemotherapy alone. Allogeneic hematopoietic cell transplantation (HCT) is a procedure that has the potential to cure such cancers not only by replacing a patient's diseased hematopoietic stem cells with healthy donor cells, but also by harnessing the benefit of a new donor immune system to eradicate any residual malignant cells. Although initial donor stem cell engraftment occurs relatively quickly and reliably [1], the early months after an allogeneic HCT are associated with profound deficits in immune function. Furthermore, many patients will experience a decline in function of their transplanted cells, manifested by secondary cytopenias and life-threatening immunodeficiencies, occurring when post-transplant complications are encountered, principally graft-versus-host disease (GVHD) [2,3]. A deeper understanding of the mechanisms behind secondary posttransplant lymphohematopoietic failure, and new methods to intervene upon this complication, are needed to improve survival in allogeneic HCT recipients. While standard options include administration of growth factors (i.e., G-CSF) or donor lymphocyte infusions, novel cellular therapeutic options under current investigation include the infusion of mesenchymal stromal cells (MSC) as a means to restore allograft hematopoietic function and possibly improve immune homeostasis after complications of allogeneic HCT.

Despite several advances in the care of HCT recipients in recent years, approximately half of all patients undergoing allogeneic HCT do not survive longer than 2 years beyond the transplant procedure [4]. Clinical predictors associated with improved survival after allogeneic HCT include rapid and complete immune reconstitution and normalization of blood counts [2,5]. After HCT, lymphocyte recovery is widely regarded as a surrogate marker for immune recovery [6-16]. We and others have shown that the absolute lymphocyte count (ALC) at approximately three months post-HCT is predictive of survival, regardless of the underlying disease for which the transplant was performed, and regardless of the conditioning regimen (myeloablative versus reduced intensity) [2,9] (and manuscript under review). However, we have also shown that the absolute monocyte count (AMC) at the day +100 time point is an important surrogate of long-term survival, with both reduced transplant-related mortality (TRM) [2] as well as a decreased relapse risk in those achieving normal monocyte counts by day +100 (manuscript under review). Another study of 30 patients has shown an association of monocyte recovery at day +90 and decreased chronic graft-versus-host disease (GVHD) and relapse risk [17]. Others have shown an increased risk of invasive fungal infections in those with severe post-transplant monocytopenia [18]. Therefore, emerging data supports that recovery of monocytes may be as important as that of lymphocytes in post-transplant immune reconstitution.

Thrombocytopenia is also increasingly recognized as a poor prognostic finding in the early post-transplant period [3]. In patients with early recovery of platelet counts but subsequent development of severe thrombocytopenia, the phenomenon of secondary failure of platelet recovery (SFPR) has been described. In allogeneic HCT recipients, SFPR has been described at a median of 63 days (21-156) post-transplant, and associated with a hazard ratio for death of 2.6 [19]. Recovery of which specific cell type- lymphocytes, monocytes, platelets, or other yet unspecified subset, or a pattern of multiple cell types - that can best predict post-transplant outcomes at the day +100 time point is currently unknown. It is possible that critical early, posttransplant events may be reflected in day +100 post-HCT cytopenias and serve as indicators for patients at risk for poor outcomes. A variety of factors, including infections, medication effects, GVHD, graft rejection, and impending relapse can result in cytopenias in patients following allogeneic HCT. We are currently working toward defining the severity of secondary cytopenias that place patients at risk for poor outcomes based upon complete blood count parameters at the day +100 evaluation through the Center for International Blood and Marrow Transplant Research. If we can successfully develop a risk-stratification tool based upon post-transplant cytopenias, the natural next step is to develop a clinical trial aimed at improvement of secondary hematopoietic failure in these patients at risk for poor survival. It is unlikely that manipulation of existing immune suppression (predominantly calcineurin inhibitors) would markedly impact hematopoiesis and subsequent outcomes, and we would therefore propose that any clinical trial be aimed at directly addressing the mechanisms behind the described phenomenon.

Mouse models have provided initial insights into the mechanisms behind the profound lymphopenia and hematopoietic failure that can be observed with severe GVHD reactions. Both reduced thymic output

*Corresponding author: Shernan G Holtan, MD, Assistant Professor, Center for Hematologic Malignancies, Knight Cancer Institute, Oregon Health \& Science University, 3181 SW Sam Jackson Park Road, Portland, OR 97219, USA, Tel: 503494-4606; Fax: 503-494-1552; E-Mail: holtan@ohsu.edu

Received October 16, 2012; Accepted October 17, 2012; Published October 19 2012

Citation: Holtan SG, Newell LF, Chandran R, Markovic SN, Porrata LF (2012) Repairing Damaged Goods: Mesenchymal Stromal Cell Therapy for Secondary Failure of Hematopoiesis Post-Allogeneic Hematopoietic Cell Transplant. J Stem Cell Res Ther 2:e109. doi:10.4172/2157-7633.1000e109

Copyright: (C) 2012 Holtan SG. This is an open-access article distributed under the terms of the Creative Commons Attribution License, which permits unrestricted use, distribution, and reproduction in any medium, provided the original author and source are credited. 
Citation: Holtan SG, Newell LF, Chandran R, Markovic SN, Porrata LF (2012) Repairing Damaged Goods: Mesenchymal Stromal Cell Therapy for Secondary Failure of Hematopoiesis Post-Allogeneic Hematopoietic Cell Transplant. J Stem Cell Res Ther 2:e109. doi:10.4172/2157$7633.1000 \mathrm{e} 109$

Page 2 of 3

and perturbation of the peripheral $\mathrm{T}$ cell compartment secondary to lymphoid organ microenvironmental damage lead to marked $\mathrm{T}$ lymphopenia in mice with GVHD [20]. Additionally, hematopoietic stem cells fail to proliferate due to downregulation of CCND1 and MYC, both negatively regulated by interferon-gamma [21]. Together, these early results suggested that both problems with lymphoid and hematopoietic microenvironment as well as inflammatory cytokines contribute to reduced lymphohematopoiesis. Given the complex interaction between hematopoietic stem cells and their microenvironment, as well as the contribution of cytokine signaling, it has subsequently been theorized that maintenance of stromal integrity and anti-inflammatory cytokine secretion provided by supplemental MSCs could abrogate this effect [22].

MSCs are pluripotent cells with the potential to differentiate into layers of mesoderm (bone, cartilage, fat). They have been theorized to be progenitor cells for the bone marrow stroma, and thus thought to potentially be able to affect hematopoiesis and marrow regeneration after the stroma-damaging chemotherapy and/or radiation conditioning given prior to HCT [23]. NOD/SCID xenograft models have demonstrated that MSCs can support the hematopoietic reconstitution of myeloid, lymphoid, and megakaryocytic lineages [24], as well as facilitate human cord blood stem cell engraftment into NOD/SCID mice, especially at low transplanted doses of cord blood stem cells [25]. Additionally, MSCs have a low immunogenic profile, and have been shown to modulate $\mathrm{T}$ cell function in in vitro assays [26,27].

The first clinical trial of HLA-matched sibling-derived MSCs given prior to HCT demonstrated safety and feasibility, although no clear beneficial signal in terms of improved engraftment or reduced GVHD rates compared with historically reported outcomes was identified in this heterogeneous group of patients [28]. However, subsequent clinical trials of alternate, non-HLA matched donor MSC co-transplantation have suggested benefit in the engraftment of hematopoietic stem cells $[23,29,30]$. For example, in a series of 14 children undergoing haploidentical HCT [29], co-infusion of haploidentical MSCs was associated with improved lymphocyte (especially natural killer cell) recovery and reduced graft failure rates ( $0 \%$ versus $15 \%$ in historical controls). No patient died of GVHD and only 2 died of relapse in the MSC-treated cohort, compared to death due to GVHD and relapse in 2 and 7 patients in the historical control cohort, respectively. While early infusion of MSCs may improve engraftment and possibly immune reconstitution, whether their later use can improve secondary cytopenias has not yet been proven in controlled studies. Encouragingly, MSC infusions have been reported to durably rescue four allogeneic HCT recipients from severe cytopenias in a recent case series (3 with refractory thrombocytopenia, 1 with refractory neutropenia) [31]. Additionally, a report of recovery from pure red cell aplasia in $\mathrm{ABO}$ mismatched HCT has recently been published [32].

Given the association of acute GVHD and secondary cytopenias [33-36], it is possible that the marrow is a GVHD target organ amenable to MSC homing and repair. Some studies have shown low level persistence of infused MSCs in damaged organs, including marrow [29]. For example, haploidentical MSCs could be identified in the bone marrow biopsy of a patient with severe aplastic anemia [37]. Additionally, after infusion for steroid-resistant GVHD, thirdparty donor HLA-mismatched MSC DNA could be identified in organs affected by GVHD but not in healthy tissue [38]. With trials incorporating MSCs for the treatment of steroid-refractory GVHD showing promise [38-40], it seems plausible to focus additional efforts on whether and how MSC infusions could be used to treat established lymphohematopoetic graft-versus-host reactions.

Future studies of the optimal timing of MSC infusions (i.e., as prophylaxis or as treatment of post-transplant complications), coupled with correlative studies of hematopoietic and immune function, will be required to determine the most appropriate application for MSC infusions in allogeneic HCT. Several additional areas of debate surrounding the use of MSC regenerative therapy remain, including the best source of MSCs (i.e., matched sibling, haploidentical, or thirdparty donor) and the optimum dose of MSC/kilogram patient body weight necessary to effect a response. Several complexities regarding how best to generate MSCs as a cellular therapy, including the creation of suitable fetal bovine serum-free culture conditions to reduce the risk of zoonoses and allergic reactions, are highlighted in the article presented by Khanna-Jain et al. [41], in this issue of Journal of Stem Cell Research and Therapy. Ongoing research into stromal cell source (marrow, adipose tissue, placenta/umbilical cord blood, dental pulp), the ideal culture conditions, cytokine cocktails, and possibility of priming of MSCs prior to infusion, all contribute to the complexity of MSC therapy. While the regenerative potential of stromal cell therapy in allogeneic HCT is very promising based upon extensive pre-clinical data and early clinical trial results, whether this could be a durable, cost-effective method to repair a damaged lymphohematopoietic system remains to be tested in a controlled fashion.

\section{References}

1. Schriber J, Agovi MA, Ho V, Ballen KK, Bacigalupo A, et al. (2010) Second unrelated donor hematopoietic cell transplantation for primary graft failure. Bio Blood Marrow Transplant 16: 1099-1106.

2. Thoma MD, Huneke TJ, DeCook LJ, Johnson ND, Wiegand RA, et al. (2012) Peripheral blood lymphocyte and monocyte recovery and survival in acute leukemia postmyeloablative allogeneic hematopoietic stem cell transplant. Bio Blood Marrow Transplant 18: 600-677.

3. Ramírez P, Brunstein CG, Miller B, Defor T, Weisdorf D, et al. (2011) Delayed platelet recovery after allogeneic transplantation: a predictor of increased treatment-related mortality and poorer survival. Bone Marrow Transplant 46: 981-986.

4. Pasquini MC, Wang Z (2011) Current use and outcome of hematopoietic stem cell transplantation: CIBMTR Summary Slides.

5. Parkman R, Cohen G, Carter SL, Weinberg KI, Masinsin B, et al. (2006) Successful immune reconstitution decreases leukemic relapse and improves survival in recipients of unrelated cord blood transplantation. Biol Blood Marrow Transplant 12: 919-927.

6. Pavletic ZS, Joshi SS, Pirruccello SJ, Tarantolo SR, Kollath J, et al. (1998) Lymphocyte reconstitution after allogeneic blood stem cell transplantation for hematologic malignancies. Bone Marrow Transplant 21: 33-41.

7. Kumar S, Chen MG, Gastineau DA, Gertz MA, Inwards DJ, et al. (2001) Effect of slow lymphocyte recovery and type of graft-versus-host disease prophylaxis on relapse after allogeneic bone marrow transplantation for acute myelogenous leukemia. Bone Marrow Transplant 28: 951-956.

8. Kumar S, Chen MG, Gastineau DA, Gertz MA, Inwards DJ, et al. (2003) Lymphocyte recovery after allogeneic bone marrow transplantation predicts risk of relapse in acute lymphoblastic leukemia. Leukemia 17: 1865-1870.

9. Kim DH, Sohn SK, Won DI, Lee NY, Suh JS, et al. (2006) Rapid helper T-cell recovery above $200 \times 106 / /$ at 3 months correlates to successful transplant outcomes after allogeneic stem cell transplantation. Bone Marrow Transplant 37: 1119-1128

10. Heining C, Spyridonidis A, Bernhardt E, Schulte-Mönting J, Behringer D, et al. (2007) Lymphocyte reconstitution following allogeneic hematopoietic stem 
Citation: Holtan SG, Newell LF, Chandran R, Markovic SN, Porrata LF (2012) Repairing Damaged Goods: Mesenchymal Stromal Cell Therapy for Secondary Failure of Hematopoiesis Post-Allogeneic Hematopoietic Cell Transplant. J Stem Cell Res Ther 2:e109. doi:10.4172/21577633.1000e109

cell transplantation: a retrospective study including 148 patients. Bone Marrow Transplant 39: 613-622

11. Le Blanc K, Barrett AJ, Schaffer M, Hägglund H, Ljungman $P$, et al. (2009) Lymphocyte recovery is a major determinant of outcome after matched unrelated myeloablative transplantation for myelogenous malignancies. Biol Blood Marrow Transplant 15: 1108-1115.

12. Matthews K, Lim Z, Pearce L, Pagliuca A, Alejandro Madrigal J, et al. (2010) Rapid recovery of lymphocyte subsets is not associated with protection from relapse of myelodysplastic syndromes and acute myeloid leukaemia after haematopoietic stem cell transplantation using a reduced intensity conditioning regimen and alemtuzumab. $\mathrm{Br} \mathrm{J}$ Haematol 149: 879-889.

13. Bühlmann L, Buser AS, Cantoni N, Gerull S, Tichelli A, et al. (2010) Lymphocyte subset recovery and outcome after T-cell replete allogeneic hematopoietic SCT. Bone Marrow Transplant 46: 1357-1366.

14. Burke MJ, Vogel RI, Janardan SK, Brunstein C, Smith AR, et al. (2011) Early lymphocyte recovery and outcomes after umbilical cord blood transplantation (UCBT) for hematologic malignancies. Biol Blood Marrow Transplant 17: 831 840 .

15. Ciurea SO, Mulanovich V, Jiang $Y$, Bassett $R$, Rondon G, et al. (2011) Lymphocyte recovery predicts outcomes in cord blood and $\mathrm{T}$ cell-depleted haploidentical stem cell transplantation. Biol Blood Marrow Transplant 17: 1169-1175.

16. Fedele R, Martino M, Garreffa C, Messina G, Console G, et al. (2012) The impact of early CD4+ lymphocyte recovery on the outcome of patients who undergo allogeneic bone marrow or peripheral blood stem cell transplantation. Blood Transfus 10: 174-180.

17. Rommeley M, Spies-Weisshart B, Schilling K, Hochhaus A, Sayer HG, et al. (2011) Reconstitution and functional analyses of neutrophils and distinct subsets of monocytes after allogeneic stem cell transplantation. J Cancer Res Clin Oncol 137: 1293-1300.

18. Parody R, Martino R, Sánchez F, Subirá M, Hidalgo A, et al. (2009) Predicting survival in adults with invasive aspergillosis during therapy for hematological malignancies or after hematopoietic stem cell transplantation: Single-center analysis and validation of the Seattle, French, and Strasbourg prognostic indexes. Am J Hematol 84: 571-578.'

19. Bruno B, Gooley T, Sullivan KM, Davis C, Bensinger WI, et al. (2001) Secondary failure of platelet recovery after hematopoietic stem cell transplantation. Biol Blood Marrow Transplant 7: 154-162.

20. Dulude G, Roy DC, Perreault C (1999) The effect of graft-versus-host disease on T cell production and homeostasis. J Exp Med 189: 1329-1342.

21. Delisle JS, Gaboury L, Bélanger MP, Tassé E, Yagita H, et al. (2008) Graftversus-host disease causes failure of donor hematopoiesis and lymphopoiesis in interferon-gamma receptor-deficient hosts. Blood 112: 2111-2119.

22. Majumdar MK, Thiede MA, Haynesworth SE, Bruder SP, et al. (2000) Human marrow-derived mesenchymal stem cells (MSCs) express hematopoietic cytokines and support long-term hematopoiesis when differentiated toward stromal and osteogenic lineages. J Hematother Stem Cell Res 9: 841-848.

23. Le Blanc K, Samuelsson H, Gustafsson B, Remberger M, Sundberg B, et al. (2007) Transplantation of mesenchymal stem cells to enhance engraftment of hematopoietic stem cells. Leukemia 21: 1733-1738.

24. Angelopoulou M, Novelli E, Grove JE, Rinder HM, Civin C, et al. (2003) Cotransplantation of human mesenchymal stem cells enhances human myelopoiesis and megakaryocytopoiesis in NOD/SCID mice. Exp Hematol 31: 413-420

25. in 't Anker PS, Noort WA, Kruisselbrink AB, Scherjon SA, Beekhuizen W, et al. (2003) Nonexpanded primary lung and bone marrow-derived mesenchymal cells promote the engraftment of umbilical cord blood-derived CD34(+) cells in NOD/SCID mice. Exp Hematol 31: 881-889.

26. Bartholomew A, Sturgeon C, Siatskas M, Ferrer K, Mclntosh K, et al. (2002) Mesenchymal stem cells suppress lymphocyte proliferation in vitro and prolong skin graft survival in vivo. Exp Hematol 30: 42-48.

27. Di Nicola M, Carlo-Stella C, Magni M, Milanesi M, Longoni PD, et al. (2002) Human bone marrow stromal cells suppress T-lymphocyte proliferation induced by cellular or nonspecific mitogenic stimuli. Blood 99: 3838-3843.

28. Lazarus HM, Koc ON, Devine SM, Curtin P, Maziarz RT, et al. (2005)
Cotransplantation of HLA-identical sibling culture-expanded mesenchyma stem cells and hematopoietic stem cells in hematologic malignancy patients. Biol Blood Marrow Transplant 11: 389-398.

29. Ball LM, Bernardo ME, Roelofs H, Lankester A, Cometa A, et al. (2007) Cotransplantation of ex vivo expanded mesenchymal stem cells accelerates lymphocyte recovery and may reduce the risk of graft failure in haploidentical hematopoietic stem-cell transplantation. Blood 110: 2764-2767.

30. Macmillan ML, Blazar BR, DeFor TE, Wagner JE (2009) Transplantation of ex-vivo culture-expanded parental haploidentical mesenchymal stem cells to promote engraftment in pediatric recipients of unrelated donor umbilical cord blood: results of a phase I-II clinical trial. Bone Marrow Transplant 43: 447-454

31. Sánchez-Guijo FM, López-Villar O, López-Anglada L, Villarón EM, Muntión S, et al. (2012) Allogeneic mesenchymal stem cell therapy for refractory cytopenias after hematopoietic stem cell transplantation. Transfusion 52: 1086-1091.

32. Sergeevicheva V, Kruchkova I, Chernykh E, Shevela E, Kulagin A, et al. (2012) Rapid Recovery from Chronic PRCA by MSC Infusion in Patient after Major ABO-Mismatched alloSCT. Case Report Med 2012: 862721.

33. Peralvo J, Bacigalupo A, Pittaluga PA, Occhini D, Van Lint MT, et al. (1987) Poor graft function associated with graft-versus-host disease after allogeneic marrow transplantation. Bone Marrow Transplant 2: 279-285.

34. Dominietto A, Raiola AM, van Lint MT, Lamparelli T, Gualandi F, et al. (2001) Factors influencing haematological recovery after allogeneic haemopoietic stem cell transplants: graft-versus-host disease, donor type, cytomegalovirus infections and cell dose. Br J Haematol 112: 219-227.

35. Terwey TH, Kim TD, Kochman AA, Hubbard VM, Lu S, et al. (2005) CCR2 is required for CD8-induced graft-versus-host disease. Blood 106: 3322-3330.

36. Raiola AM, Van Lint MT, Valbonesi M, Lamparelli T, Gualandi F, et al. (2003) Factors predicting response and graft-versus-host disease after donor lymphocyte infusions: a study on 593 infusions. Bone Marrow Transplant 31 687-693.

37. Fouillard L, Bensidhoum M, Bories D, Bonte H, Lopez M, et al. (2003) Engraftment of allogeneic mesenchymal stem cells in the bone marrow of a patient with severe idiopathic aplastic anemia improves stroma. Leukemia 17 474-476.

38. Ringdén O, Uzunel M, Rasmusson I, Remberger M, Sundberg B, et al. (2006) Mesenchymal stem cells for treatment of therapy-resistant graft-versus-host disease. Transplantation 81: 1390-1397.

39. Le Blanc K, Frassoni F, Ball L, Locatelli F, Roelofs H, et al. (2008) Mesenchymal stem cells for treatment of steroid-resistant, severe, acute graft-versus-host disease: a phase II study. Lancet 371: 1579-1586.

40. Bernardo ME, Ball LM, Cometa AM, Roelofs H, Zecca M, et al. (2011) Coinfusion of ex vivo-expanded, parental MSCs prevents life-threatening acute GVHD, but does not reduce the risk of graft failure in pediatric patients undergoing allogeneic umbilical cord blood transplantation. Bone Marrow Transplant 46: 200-277.

41. Khanna-Jain R, Vanhatupa S, Vuorinen A, Sandor GKB, Suuronen R, et al (2012) Growth and differentiation of human dental pulp stem cells maintained in fetal bovine serum, human serum and serum-free/xeno-free culture media. $J$ Stem Cell Res Ther 2: 1-11. 